\title{
Ecological Characteristics of Triatoma patagonica at the Southern Limit of its Distribution (Chubut, Argentina)
}

\author{
Cristina Wisnivesky-Colli/ ${ }^{+}$, Darío Vezzani, Silvia M Pietrokovsky, Hugo Scurti*, \\ Jorge Iriarte*
}

\begin{abstract}
Unidad de Ecología de Reservorios y Vectores de Parásitos, Departamento de Ecología, Genética y Evolución, Facultad de Ciencias Exactas y Naturales, Universidad de Buenos Aires, Pabellón II, Ciudad Universitaria, Nuñez (C1428EHA), Buenos Aires, Argentina *Dirección de Control de Patologías Prevalentes, Sistema Provincial de Salud de la Provincia del Chubut, Argentina
\end{abstract}

This study aimed at identifying the ecological characteristics of Triatoma patagonica Del Ponte 1929(Hemiptera: Reduviidae) and evaluating the epidemiological importance of this species at its southernmost distribution limit. We carried out two surveys in the Province of Chubut, in summer and in spring, 1998. In each survey, we interviewed local health care agents for triatomine recognition and reports of the bugs, followed by entomological searches in houses and peridomestic and silvatic biotopes. The presence of $\mathrm{T}$. patagonica was confirmed in two of the five localities indicated by interview. In agreement with previous studies, all these positive localities were east of the $11^{\circ} \mathrm{C}$ isotherm, within the Monte phytogeographic province. Triatomine abundance and infestation levels (in peridomiciles and peridomestic biotopes) were higher in summer than in spring, possibly reflecting adverse environmental conditions such as flood and cold winter weather. In the silvatic environment, we found three adult bugs under rocks in summer. In peridomestic sites bugs were only found associated with chickens, which were also the only blood meal source identified. Infection by Trypanosoma cruzi was not detected. We conclude that $\mathrm{T}$. patagonica at its southernmost distribution limit does not represent a risk to public health due to its low abundance, lack of association with humans, and absence of T. cruzi infection.

Key words: Triatoma patagonica - Triatoma infestans - Trypanosoma cruzi - biotopes - silvatic triatomines - Patagonia

In the last decade, countries of the southern cone of South America have combined efforts through the Southern Cone Initiative to eliminate the main domestic vector of Chagas disease, Triatoma infestans Klug (Hemiptera: Reduviidae) (Schmunis et al. 1996). This campaign has been successful to control such vector (Schofield \& Diaz 1999) but may provide opportunities for other triatomine species to become epidemiologically relevant. In Argentina, the main candidates to occupy the vacant niche left by $T$. infestans would be the silvatic and peridomestic species of the sordida group: T. sordida Stål (Bar et al. 2002), T. guasayana Wygodzinsky \& Abalos (Gajate et al. 1996), and T. patagonica Del Ponte. The former two species have been intensively studied (Forattini et al. 1982, Wisnivesky-Colli et al. 1997, Rocha Pires et al. 1999, Bar \& Wisnivesky-Colli 2001, Vezzani et al. 2001), but there is comparatively little information available on the ecology of T. patagonica and current knowledge is based on non-methodical studies.

T. patagonica is the southernmost silvatic triatomine of the Americas. It has been reported from central, western and southern provinces of Argentina (Abalos \& Wy-

Financial support: SiProSalud (Provincia de Chubut) and UBACyT project Ty13

${ }^{+}$Corresponding author. Fax: +54-11-47834164. E-mail: criswi@bg.fcen.uba.ar, criswi@maderonet.com.ar

Received 1 August 2003

Accepted 10 October 2003 godzinsky 1951, Lent \& Wygodzinsky 1979), of which the Patagonian province of Chubut represents its southernmost distribution limit (Bejarano et al. 1967, Virla de Arguello 1984). T. patagonica seems able to develop substantial colonies in peridomestic artificial biotopes such as chicken coops and animal pens (Virla de Arguello 1984). Susceptibility of this species to infection with Trypanosoma cruzi (causative agent of Chagas disease) has been demonstrated experimentally (Mazza 1937) and also by the occasional finding of naturally infected nymphs in peridomestic biotopes (Abalos \& Wygodzinsky 1951).

We report here a study designed to identify the ecological characteristics of T. patagonica and to evaluate the epidemiological importance of this species at its southernmost distribution area.

\section{MATERIALS AND METHODS}

The study area was located in the Province of Chubut, Argentina (Fig. 1). This area is part of the Patagonian plateau, a vast semi-desert region crossed by several rivers from west to east. Annual mean temperature ranges from $4^{\circ} \mathrm{C}$ at the eastern slopes of the Andes (2000 m a.s.l.) to $16^{\circ} \mathrm{C}$ at the Atlantic coast (INDEC 1995). Population density is low (about 1 inhabitant $/ \mathrm{km}^{2}$ ), and intense overgrazing by sheep together with heavy deforestation led to a serious desertification (INTA 1993).

The region comprises the Monte and Patagonian phytogeographic provinces (Cabrera \& Willink 1973). The climate of the Monte is dry and temperate; mean annual rainfall ranges between 80 and $250 \mathrm{~mm}$, and mean annual temperature between 13 and $15.5^{\circ} \mathrm{C}$. The dominant vegetation type is a shrub-steppe with scrubs $1-2 \mathrm{~m}$ high. 
The climate of the Patagonian phytogeographic province is dry and temperate-cold, with strong winds blowing from the west, snowfall taking place in winter with frosts throughout most of the year; mean annual rainfall ranges between 100 and $270 \mathrm{~mm}$, and mean annual temperature between 5 and $13.4^{\circ} \mathrm{C}$. Here, the shrub-steppe is also the dominant vegetation type, although it is characterized by the dominance of shrubs with cushion-like appearance (Cabrera \& Willink 1973).

In order to choose the study area, an attempt was made to associate environmental conditions with the sites documented as positive for T. patagonica (Bejarano et al. 1967). When such localities were included in a regional map of isotherms (Vallejo \& Coronato 1994) and phytogeographic provinces (INDEC 1995), we observed that they were all located east of the $11^{\circ} \mathrm{C}$ isotherm and within the Monte phytogeographic province (Fig. 1). Based on these preliminary results we selected eight localities situated east of the $11^{\circ} \mathrm{C}$ isotherm and within the Monte phytogeographic province, together with seven localities west of this isotherm and within the Patagonian phytogeographic province (Fig. 1). Five out of these 15 localities had been previously reported as infested by $T$. patagonica (Bejarano et al. 1967, Virla de Arguello 1984).

In our sampling we included farms belonging to immigrants from endemic areas of Chagas disease, who periodically visited their region of origin.

Two surveys were carried out during 1998, the first in summer (January) and the second in spring (October). Just prior to the second survey, a flood affected the dwellings of locations along the bank of the Chubut River. The locality of Gaiman was visited in both surveys to evaluate the impact of the flood on the triatomine population. Sites visited in January comprise points 1-10, and in October these are referred to as points 1 and 11-15 in Fig. 1.

In each study location, we carried out the following routine: (1) we visited the local Sanitary Unit (Hospital or Primary Health Care Unit) to interview doctors, nurses and Primary Health Care agents about the reported
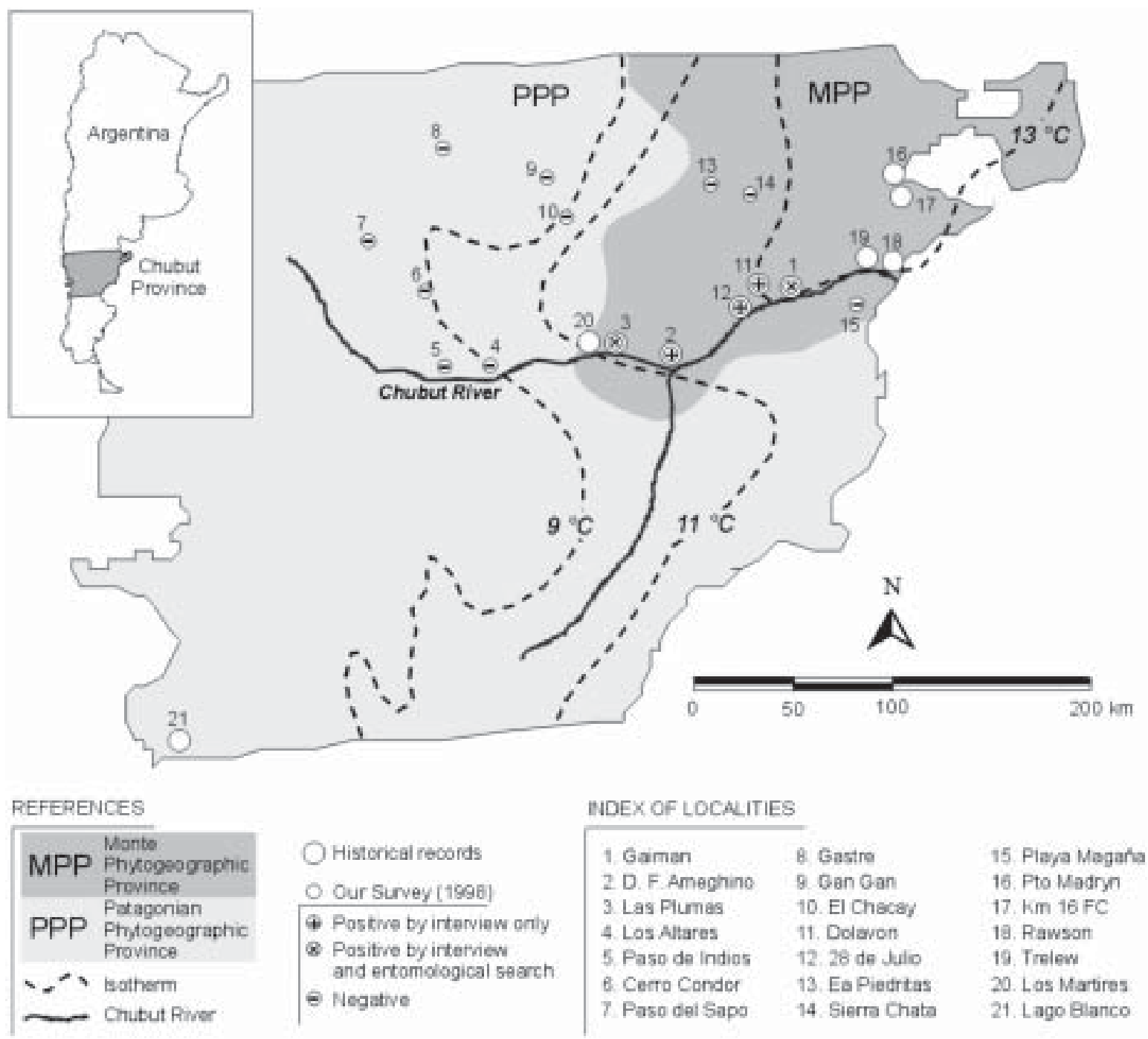

Fig. 1: map of Province of Chubut (Argentina), with the phytogeographic provinces (INDEC 1995), the isotherms (Vallejo \& Coronato 1994), the localities currently surveyed and those mentioned in literature as historical records for Triatoma patagonica (Bejarano et al. 1967, Virla de Arguello 1984). 
presence of triatomines in the area. We also showed them a collection of nymphs and adults of T. patagonica for recognition; (2) if presence of bugs had been noticed and infested houses were identified, we carried out an entomological search in all biotopes within the peridomicile of such houses. Domiciles were also inspected indoors when triatomines were found in peridomiciles and/or when inhabitants reported the presence of adult bugs attracted to house lights; (3) species of domestic animals close to infested peridomestic biotopes were recorded.

Within the peridomestic area of each house we examined a series of possible habitats (biotopes) for $T$. patagonica. These biotopes included chicken houses, pig pens, store-rooms, log piles, boards, bricks and flat stones, and wooden boxes. Silvatic habitats in the vicinity of the houses were also examined for the presence of triatomines regardless of whether or not bugs had been found in the houses or associated peridomestic areas. Silvatic biotopes comprised caves in hills, burrows of small mammals, roots of shrubs and piled rocks. We used the timed collection method, sometimes applying a flushingout agent $(0.2 \%$ tetramethrin) (Wisnivesky-Colli et al. 1987). Two persons examined each biotope for $30 \mathrm{~min}$ (capture effort $1 \mathrm{~h} /$ person) in search of direct evidence (insects, exuviae, eggs) and indirect evidence (faecal streaks) of triatomines.

All triatomines collected were grouped by individual biotope and put into labeled plastic bags with pleated absorbent paper. In our laboratory in Buenos Aires, they were identified following Lent and Wygodzinsky (1979) and classified by sex and instar.

Rectal contents of the bugs were examined microscopically to determine trypanosome infection (Wisnivesky-Colli et al. 1982). The feeding pattern of collected triatomines was analyzed by the Oucherlony test using rabbit antisera against blood proteins of human, chicken, pig, dog, cat, and murids (Wisnivesky-Colli et al. 1982).

The $\chi^{2}$ test was used to compare the proportions of infested peridomiciles and peridomestic biotopes between summer and spring (Fleiss 1981).

\section{RESULTS}

T. patagonica was the only species of triatomine encountered. Interviews at the local sanitary units revealed five infested localities, all of which were situated east of the $11^{\circ} \mathrm{C}$ isotherm and within the Monte phytogeographic province. At these sites, however, we could confirm the presence of $T$. patagonica by entomological search only in Gaiman (summer and spring) and Las Plumas (summer) (Fig. 1).

The proportion of infested peridomiciles in summer $(5 / 12,41 \%)$ was significantly higher than that of spring $(1 / 25,4 \%)\left(\chi^{2}=5.921, \mathrm{p}<0.05\right)$. Inside houses the only specimens recorded were three adults in summer.

A total of $7.1 \%(15 / 210)$ of the biotopes examined were infested, and significant differences $\left(\chi^{2}=11.389, \mathrm{p}<0.001\right)$ were found between summer $(13 / 88,14.8 \%)$ and spring $(2 /$ $122,1.6 \%)$. All triatomines were found in places used by hens for resting such as henhouses, wooden boxes and log piles, boards, bricks and flat stones.

In silvatic habitats, we collected only three $T$. patagonica females under rocks in caves located $300 \mathrm{~m}$ far from houses, which were used by dogs for shelter and breeding.

After the flood, a layer of dry mud up to $1 \mathrm{~m}$ high covered the biotopes of almost all the peridomiciles in the locality of Gaiman. The entomological search in the peridomicile that had shown the heaviest infestation (56 individuals) in summer rendered negative results the following spring. Triatomines were only found in the peridomicile of an elevated dwelling that had not been affected by the flood.

From all the searches, a total of 137 insects was collected, 115 in summer and 22 in spring, and all of them were identified as T. patagonica. The population structure of triatomines collected in summer is shown in Fig. 2. In the spring, we found two first instar nymphs $\left(\mathrm{N}_{1}\right), 10 \mathrm{~N}_{2}$, $8 \mathrm{~N}_{3}, 1 \mathrm{~N}_{4}$, and 1 male. Females were only encountered in the summer collections, and five of these oviposited inside the plastic bag during transport to the laboratory. Those 124 insects found alive upon arrival at the laboratory were examined for food content. Among these, 14 triatomines had blood in their midgut, and the blood meal source could be determined in 13, which had fed on chicken. Sixty-seven bugs were examined for T. cruzi and none of them was infected (Table).

In 16 out of 37 visited households, inhabitants reported adults landing indoors from the end of December to late January.

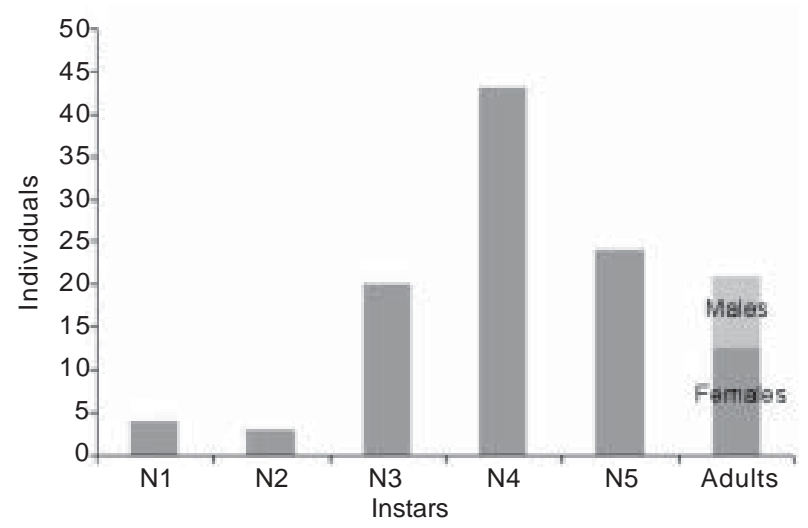

Fig. 2: population structure of Triatoma patagonica in summer

TABLE

Trypanosoma cruzi infection and feeding pattern by stage and sex in Triatoma patagonica

\begin{tabular}{lcrrrr}
\hline & \multicolumn{5}{c}{ Number of triatomines } \\
\cline { 2 - 6 } & N1-N3 & N4-N5 & F & M & Total \\
\hline Collected & 47 & 68 & 13 & 11 & 139 \\
Examined for T. cruzi & 21 & 34 & 9 & 3 & 67 \\
Examined for food content & 47 & 61 & 10 & 6 & 124 \\
Feeding source (chicken) & 1 & 9 & 1 & 2 & 13 \\
\hline
\end{tabular}


In the 25 examined biotopes of the five farms inhabited by immigrants from endemic areas of Chagas disease, there was no direct or indirect evidence of triatomines.

\section{DISCUSSION}

The Argentine province of Chubut has been little studied in relation to Triatominae and the transmission of Chagas disease, as it is close to the southernmost limits reported for the whole subfamily of Triatominae (Schofield 1994). The occurrence of T. infestans in some localities of Chubut included in our study area was documented by Jörg (1959). However, our survey showed no evidence for the continuing presence of T. infestans, either by epidemiological questionnaire or from our entomological searches. T. infestans could be accidentally carried into the area by immigrants from other regions, but we suspect that the environmental conditions would be unsuitable for establishment of colonies of this species.

By contrast, our study lends support to our initial appraisal that in Chubut, T. patagonica is confined to areas east of the $11^{\circ} \mathrm{C}$ isotherm, within the Monte phytogeographic province. T. patagonica, like other secondary vectors of Chagas disease such as T. sordida and $T$. guasayana, can establish considerable colonies in peridomestic biotopes (Lent \& Wygodzinsky 1979). However, although local inhabitants reported some adult bugs flying to houses at night, we did not find any evidence of domestic colonies within our study area. This is distinct from the case with T. sordida and T. guasayana which frequently give rise to small and transient colonies in the domicile (Bar et al. 2002).

There are many contrasts in the epidemiological scenario between Patagonia and the more northerly subtropical areas of Argentina that are highly endemic for Chagas disease. In Patagonia, houses are usually isolated from peridomestic premises and domestic animals are not kept indoors. Therefore, there is no flow of animals and vectors between the domicile and the peridomicile, which is usual in Northern Argentine provinces (Wisnivesky-Colli et al. 1982). On the other hand, due to climatic conditions, people rarely sleep outside the house as they do in subtropical provinces, thus diminishing the contact between humans and peridomestic vectors. The typical adobe huts of the northern provinces, which buffer extreme temperatures and provide access to abundant blood meal sources for domestic Triatominae, seem to be more favourable for triatomines than patagonian houses where blood sources are limited to people (rather than including domestic animals) and indoor temperatures are low most of the year due to the lack of appropriate heating systems.

In our study area, the concentration of T. patagonica colonies in peridomestic habitats used as resting sites by chickens, as well as the fact that chickens were the only blood meal source detected despite the presence of other animals, shows a clear association between T. patagonica and chickens. It can be speculated that these biotopes provide T. patagonica with essential conditions to survive in such a hostile region. Carcavallo (1999) considers that triatomines such as T. patagonica, T. platensis, and $T$. infestans can survive in extremely cold climates, due to the more favourable microclimatic conditions of the reservoir habitat.

In addition to climatic constraints, periodic floods in the lower valley of the Chubut River have become one of the most serious environmental concerns in the region (Serra 1999). The marked difference in infestation levels of T. patagonica between summer and spring suggests a strong effect of adverse environmental conditions such as flood and cold winter weather. The persistence of triatomine populations after environmental disturbance in the area is also difficult to understand, considering the long developmental time of this species. Carcavallo and Martínez (1968) reported a mean time from egg to adult of 238 days at a constant laboratory temperature of $26^{\circ} \mathrm{C}$. As developmental time is inversely related to temperature, the life cycle of this triatomine under field conditions is expected to be much longer.

The population structure of T. patagonica reveals that almost all the adults were collected in summer, whereas those of silvatic triatomines from Northern Argentina such as T. sordida (Bar \& Wisnivesky 2001) and T. guasayana (Vezzani et al. 2001) were only found before this season. This result may indicate a delay in the reproductive period of T. patagonica possibly related to lower spring temperatures registered in Patagonia.

The susceptibility of T. patagonica to acquire T. cruzi infection is shown by the occurrence of both natural and experimental infection (Mazza 1937, Abalos \& Wigodzinsky 1951). In addition, this species seems to be capable of transmitting T. cruzi because it defaecates while feeding on the host (Nattero et al. 2002). However, in agreement with data of Bejarano et al. (1967) and Virla de Arguello (1984) for the Province of Chubut, the specimens of $T$. patagonica collected in our survey were all uninfected, which may reflect their predominant association with chickens which are refractory to T. cruzi infection.

In brief, we concluded that $T$. patagonica at its southern distribution limit does not pose a public health threat due to its low abundance, lack of association with humans and the absence of $T$. cruzi infection.

\section{ACKNOWLEDGEMENTS}

To Dr CJ Schofield for his critical revision of the manuscript.

\section{REFERENCES}

Abalos JW, Wygodzinsky P 1951. Las Triatominae Argentinas (Reduviidae, Hemiptera), Monograph 2, Instituto de Medicina Regional, Tucumán, Argentina, 179 pp.

Bar ME, Wisnivesky-Colli C 2001. Triatoma sordida Stål 1859 (Hemiptera, Reduviidae: Triatominae) in palms of Northeastern Argentina. Mem Inst Oswaldo Cruz 96: 895-899.

Bar ME, Damborsky MP, Oscherov EB, Milano AMF, Avalos $\mathrm{G}$, Wisnivesky-Colli C 2002. Triatomes involved in domestic and wild Trypanosoma cruzi transmission in Concepción, Corrientes, Argentina. Mem Inst Oswaldo Cruz 97: 43-46.

Bejarano JFR, Rubin de Celis M, Carcavallo RU, Martinez A 1967. La enfermedad de Chagas-Mazza en la Patagonia. Segundas Jornadas Entomoepidemiológicas Argentinas, Tomo III, Salta, p. 13-54.

Cabrera AL, Willink A 1973. Biogeografía de América Latina, Monograph 13, Serie Biología, OEA, Washington, 120 pp. Carcavallo RU 1999. Climatic factors related to Chagas dis- 
eases transmission. Mem Inst Oswaldo Cruz 94 (Suppl. I): 367-369.

Carcavallo RU, Martinez A 1968. Enfermedad de Chagas y sus transmisores. In RU Carcavallo, A Martinez (eds), Entomoepidemiología de la República Argentina, XXIII Comunicaciones Científicas de las Fuerzas Armadas, Buenos Aires, p. 23-103.

Fleiss JL 1981. Statistical Methods for Rates and Proportions, 2nd ed., John Wiley \& Sons, New York, 255 pp.

Forattini OP, Soares Barata JM, Ferreira Santos JL, Silveira AC 1982. Hábitos alimentares, infecção natural e distribuição de triatomíneos domiciliados na região central do Brasil. Rev Saúde Públ São Paulo 16: 171-204.

Gajate PP, Bottazzi V, Pietrokovsky SM, Wisnivesky-Colli C 1996. Potential colonization of the peridomicile by Triatoma guasayana (Hemiptera: Reduviidae) in Santiago del Estero, Argentina. J Med Entomol 33: 635-639.

INDEC 1995. Atlas Estadístico de la Republica Argentina, Instituto Nacional de Estadísticas y Censos, Buenos Aires, Argentina.

INTA 1993. Proyecto de Prevención y Control de la Desertificación en la Patagonia/Project for Prevention and Control of Desertification in Patagonia, Instituto Nacional de Tecnología Agropecuaria, Buenos Aires, Argentina.

Jörg ME 1959. Límite sud de la dispersión geográfica de Triatoma infestans y su infestación por Trypanosoma cruzi en Argentina. In JFR Bejarano, E del Ponte, RN Orfila (eds), Primeras Jornadas Entomoepidemiológicas Argentinas (Vol. I), Dirección General de Sanidad de la Secretaría de Guerra, Buenos Aires, p. 153-162.

Lent H, Wygodzinsky P 1979. Revision of the triatominae (Hemiptera, Reduviidae) and their significance as vectors of Chagas' disease. Bull Am Mus Nat Hist 163: 123-520.

Mazza S 1937. Posición sistemática de Euritriatoma (Triatoma) patagonica. Publicación de la Misión de Estudios de las Patologías Regionales Argentinas 30: 17.

Nattero J, Crocco LB, Rodríguez CS 2002. Feeding and defaecation behaviour of Triatoma patagonica (Del Ponte, 1929) (Hemiptera: Reduviidae). Mem Inst Oswaldo Cruz 97: 10631065 .
Rocha Pires HH, Borges EC, Esteves de Andrade R, Seixas Lorosa E, Diotaiuti L 1999. Peridomiciliary infestation with Triatoma sordida Stål 1859 in the county of Serra do Ramalho, Bahia, Brazil. Mem Inst Oswaldo Cruz 94: 147-149.

Schmunis GA, Zicker F, Moncayo A 1996. Interruption of Chagas' disease transmission through vector elimination. The Lancet 348: 1171.

Schofield CJ 1994. Triatominae: Biología y Control, Eurocommunica Publications, UK, 77 pp.

Schofield CJ, Diaz JC 1999. The Southern Cone Initiative against Chagas disease. Adv Parasitol 42: 1-27.

Serra JJ 1999. Riesgo de erosión hídrica en el cuenco aluvional del área Dique F. Ameghino y Boca Toma, Valle Inferior del Río Chubut, Provincia del Chubut. Cuadernos del Curiham 5: 63-83.

Vallejo M, Coronato F 1994. Atlas de la Provincia de Chubut, Plan educativo del Ministerio de Cultura y Educación de la Nación, Buenos Aires, Argentina, 30 pp.

Vezzani D, Schweigmann N, Pietrokovsky S, Wisnivesky-Colli C 2001. Characterization of Triatoma guasayana biotopes in a hardwood forest of Santiago del Estero, Argentina. Mem Inst Oswaldo Cruz 96: 459-466.

Virla de Arguello NE 1984. Nota sobre la presencia de Triatoma patagonica Del Ponte, 1929 (Reduviidae, Triatominae) en la Provincia de Chubut, Argentina. Rev Soc Entomol Argentina 43: 57-59.

Wisnivesky-Colli C, Gürtler RE, Solarz ND, Salomón D, Ruiz AM 1982. Feeding patterns of Triatoma infestans (Hemiptera, Reduviidae) in relation to transmission of American trypanosomiasis in Argentina. J Med Entomol 19: 645-654.

Wisnivesky-Colli C, Paulone I, Perez A, Chuit R, Gualtieri J, Solarz ND, Smith A, Segura EL 1987. A new tool for continuous detection of the presence of triatomine bugs, vectors of Chagas' disease, in rural households. Medicina (Buenos Aires) 47: 45-50.

Wisnivesky-Colli C, Schweigmann N, Pietrokovsky SM, Bottazzi V, Rabinovich J 1997. Spatial distribution of Triatoma guasayana (Hemiptera: Reduviidae) in hardwood forest biotopes in Santiago del Estero, Argentina. J Med Entomol 34: 102-109. 